\title{
PENGARUH DEWAN KOMISARIS DAN KEPEMILIKAN MANAJERIAL TERHADAP INTELLECTUAL CAPITAL DISCLOSURE PADA PERBANKAN YANG TERDAFTAR DI BURSA EFEK INDONESIA
}

\author{
Olivia Kusuma ${ }^{1}$ \\ Nur Rahmanti Ratih ${ }^{2}$ \\ ${ }^{1}$ Prodi Akuntansi Fakultas Ekonomi Universitas Islam Kadiri \\ ${ }^{2}$ Prodi Akuntansi Fakultas Ekonomi Universitas Islam Kadiri
}

\begin{abstract}
Abstrak
Tujuan dari penelitian ini adalah untuk mengetahui bagimana pengaruh dewan komisaris yang diproyeksikan menjadi ukuran dewan komisaris, proporsi komisaris independen, frekuensi rapat, latar belakang pendidikan dan keberadaan wanita dan kepemilikan manajerial terhadap intellectual capital disclosure pada perbankan di Indonesia.Dengan diketahuinnya pengaruh tersebut diharpakan perusahaan dapat meningkatkan pengungkpaan yang dimilikinya.Populasi pada penelitian ini adala perbankan BUMN dan non BUMN yang terdafar di Bursa Efek Indonesia.Penentuan jumlah sempel menggunakan teknik purposive sampli dan di dapat 21 perusahaan pada periode 2015-2017. Teknik analisis data menggunakan Analisis Regresi Linier Berganda dengan taraf signifikansi < 0,05. Dari hasil analisis yang telah dilakukan, menunjukan bahwa secara parsial dari enam hipotesis menunjukan bahwa ukuran dewan komisaris memiliki pengaruh positif terhadap intellectual capital disclosure dengan nilai sig. 0,000.Proporsi dewan komisaris independen memiliki pengaruh positif terhadap intellectual capital disclosure dengan nilai sig. 0,032.Frekuensi rapat dewan komisris memiliki pengaruh positif terhadap intellectual capital disclosure dengan nilai sig. 0,019. Latar belakang pendidikan memiliki pengaruh positif terhadap intellectual capital disclosure dengan nilai sig.0,015. Dan secara simultan ukuran dewana komisaris, proporsi komisaris independen, frekuensi rapat, latar belakang pendidikan dan keberadaan wanita dan kepemilikan manajerial berpengaruh positif dengan nilai sig. 0,005 .
\end{abstract}


Jurnal Cendekia Akuntansi Vol. 1 No. 1

Kata kunci : Dewan Komisaris, Kepemilikan Manajerial, Intellectual Capital Disclosure, Indonesia.

\section{Abstract}

The purpose of this study is to know how relationship between board of commissioner that projection to be size of board commissioner, proportion of board commissioner independent, frequency meeting of, education background, woman existence of board commissioner, managerial ownership and intellectual capital disclosure in Indonesia Banking Industry. By information from this relation can give motivation for company to upgrade their intellectual capital disclosure. The population for this study is all Banking listen in Indonesia Stock Exchange, determinations of the all sample use purposive sampling method and get 21 company period 2015-2017. Data analysis technique use multiple liniear analysis with signification standard $<0,05$. Output from analysis found that as partial from six hypotheses find if size of board commissioner have positive relation about intellectual capital disclosure with sig. score 0,000. Proportion of board commissioner independent have positive relation about intellectual capital disclosure with sig. score 0,032. Meeting frequency of board commissioner have a positive relation about intellectual capital disclosure with sig. score 0,019. Education background of board commissioner have a positive relation about intellectual capital disclosure with sig. score 0,015. And as simultaneous size of board commissioner, proportion of board commissioner independent, frequency meeting of board commissioner, education background of borad commissioner, woman existence of board commissioner, managerial ownership have positive relation with intellectual capital disclosure sig. score 0,005.

Keywords : size of board commissioner,proportion of board commissioner independent, frequency meeting, education background, woman existence, managerial ownership, intellectual capital disclosure, Indonesia.

\section{PENDAHULUAN}

Globalisasi, inovasi teknologi dan persaingan yang semakin ketat pada abad ini memaksa perusahaan - perusahaan mengubah cara mereka dalam menjalankan bisnisnya. Hal ini memotivasi perusahaan-perusahaan untuk mengubah metode bisnisnya.Keadaan ini menyebabkan pelaku bisnis gencar menekankan perhatian pada aset tak berwujudnya, dalam hal ini adalah ilmu pengetahuan (Suwarjuono dalam Shella dan Wedari, 2016). Dengan ilmu pengetahuan yang tinggi diharapkan akan membuat perusahaan mampu bersaing dengan para kompetitornya, hal ini juga berlaku untuk lembaga perbankan.

Lembaga perbankan di Indonesia berdiri dan tumbuh sejalan dengan perkembangan ekonomi nasional. Perkembangan perbankan di Indonesia dibuktikan dengan banyak berdiri bank - bank baru, menurut OJK (Otoritas Jasa Keuangan) jumlah perbankan yang ada saat ini adalah 115 bank dan sebanyak 43 perbankan telah terdaftar dalam Bursa Efek Indonesia. Ditinjau dari kepemilikan modalnya terdapat empat jenis perbankan yang termasuk di dalamnya, pertama bank milik pemeritah atau biasa disebut bank BUMN dan yang kedua bank milik swasta atau biasa disebut BUMS. Kedua jenis bank ini paling banyak di temukan di Indonesai.Banyak berdirinya bank-bank baru ini mengakibatkan persaingan 
dalam dunia perbankan semakin ketat, setiap bank dituntut untuk memiliki strategi dalam memenuhi target yang telah ditentukan.

Dewan komisaris adalah orang yang memiliki peran penting dalam perbankan yang mempunyai tugas untuk mengawasi kinerja karyawan.Selain memiliki tugas mengawasi kinerja karyawan dewan komisaris juga memiliki tugas memberikan nasihat kepada dewan direksi terkait dengan strategi yang disusun oleh dewan direksi.Wewenang dewan komisaris tidak terbatas pada tugas mengawasi dan memberikan nasihat, dewan komisaris juga memiliki hak dalam kepemilikan saham dalam perbankan.Kepemilikan saham ini sering disebut dengan kepemilikan manajerial, dimana saham perusahaan dimiliki oleh organisasi maupun perorangan yang masih memiliki hubungan dengan perbankan itu sendiri. Kepemilikan manajerial oleh dewan komisaris juga dapat berimbas pada kualitas pelopran yang disajikan oleh perusahaan. Pelaporan keuangan bank tidak terbatas pada laporan keuangannya saja, perusahaan sebaikanya juga mengungkpaakan aset tak berwujud yan dimilikinya, aset beruwujud yang dapat diungkapakan oleh berusahaan salah satunya adalah intellectual capital disclosure.(Hartrianto dan Sjarief, 2017)

ICD merupakan pengungkapan modal pengetahuan yang dimiliki oleh perusahaan, pengungkapan ini dapat memberikan gambaran masa depan sebuah perusahaan. Perusahaan mengungkapkan informasi mengenai intellectual capital pada bagian profil perusahaan dan analisis pembahasan manajemen dalam laporan tahunannya. Pengungkapan ICD yang dimiliki oleh perusahaan dapat memberikan informasi tambahan kepada para investor mengenai kelangsungan hidup perusahaan di masa depan. Informasi mengenai kelangsungan hidup perusahaan yang ditampilkan dalam ICD dapat menambah nilai perusahaan.

\section{TINJAUAN PUSTAKA}

\section{Dewan Komisaris}

Dewan komisaris merupakan seseorang yang memiliki tugas untuk mengawasi kinerja dari para karyawan perusahaan dan memberikan nasihat kepada direksi terkait dengan pengambilan keputusan yang dibuat oleh direksi. Menurut Zarkasti (2008: 76)menyatakan bahwa dewan komisaris adalah organ perseroan yang bertugas melakukan pengawasan secara umum dan/atau khusus sesuai dengan anggaran dasar serta memberi nasihat kepada direksi.Menurut Kuswiratmo, (2016:53) Dewan komisaris merupakan salah satu komponen yang wajib dimiliki oleh perusahaan, dimana tugas utama dari dewan komisaris adalah melakukan pengawasan sesuan dengan anggaran dasar perusahaan dan memberikan nasihat kepada direksi terkait dengan prospek perusahaan di masa datang.

\section{Kepemilikan Manajerial}

Kepemilikan manajerial merupakan kepemilikan saham yang dimiliki oleh manajemen maupun dewan komisaris dalam perusahan.Menurut Wiryadi \& Sebrina (2013) menjelaskan bahwa kepemilikan manajerial adalah kepemilikan saham suatu perusahaan publik yang dimiliki oleh individu maupun kelompok elit yang berasal dari dalam perusahaan.Kepemilikan manajerial oleh individu dalam perusahaan dapat diperoleh dari pembelian saham perusahaan secara langsung atau sebagai apresiasi perusahaan atas kinerja individu, menurut Christiawan dan Tarigan, (2017). 
Jurnal Cendekia Akuntansi Vol. 1 No. 1

\section{Intellectual Capital Disclosure (ICD)}

Menurut Ulum (2017: 279)Intellectual Capital Disclosure (ICD)adalah pengungkapan modal intelektual yang dimiliki oleh organisasi. Pelaporan keuangan perusahaan tidak terbatas pada laporan keuangannya saja yang hanya mengungkapkan aset berwujud yang bukan merupakan alat pengambilan keputusan yang baik. Terdapat informasi lain yang dapat digunakan untuk menjeleskan nilai lebih yang dimiliki oleh perusahaan. Informasi tersebut adalah intellectual capital disclosure. Terdapat 3 elemen dalam intellectual capital disclosure yaitu sebagai berikut :

$>$ Human capitalmerupakan elemen pertamadimana untuk mengembangkan usahanya perusahaan membutuhkan seseorang yang kompeten dalam bidangnya.

$>$ Structural capital merupakan elemen kedua yaitu merupakan kemampuan pearusahaan dalam memenuhi proses aktivitas perusahaan dan strukturnya yang mendukung karyawan untuk menghasilkan kinerja intelektual serta kerja bisnis secara keseluruhan.

$>$ Relational capital merupakan elemen yang terakhirmerupakan komponen intellectual capital yang dapat memberikan nilai kepada perusahaan secara nyata. Yang terdapat pada elemen ini adalah adanya hubungan dengan pihak ketiga dalam perusahaan contohnya adalah adanya hubungan yang baik antara nasabah dan bank. (Suhardjanto dan Wardhani, 2010)

\section{Kerangka Pikir}

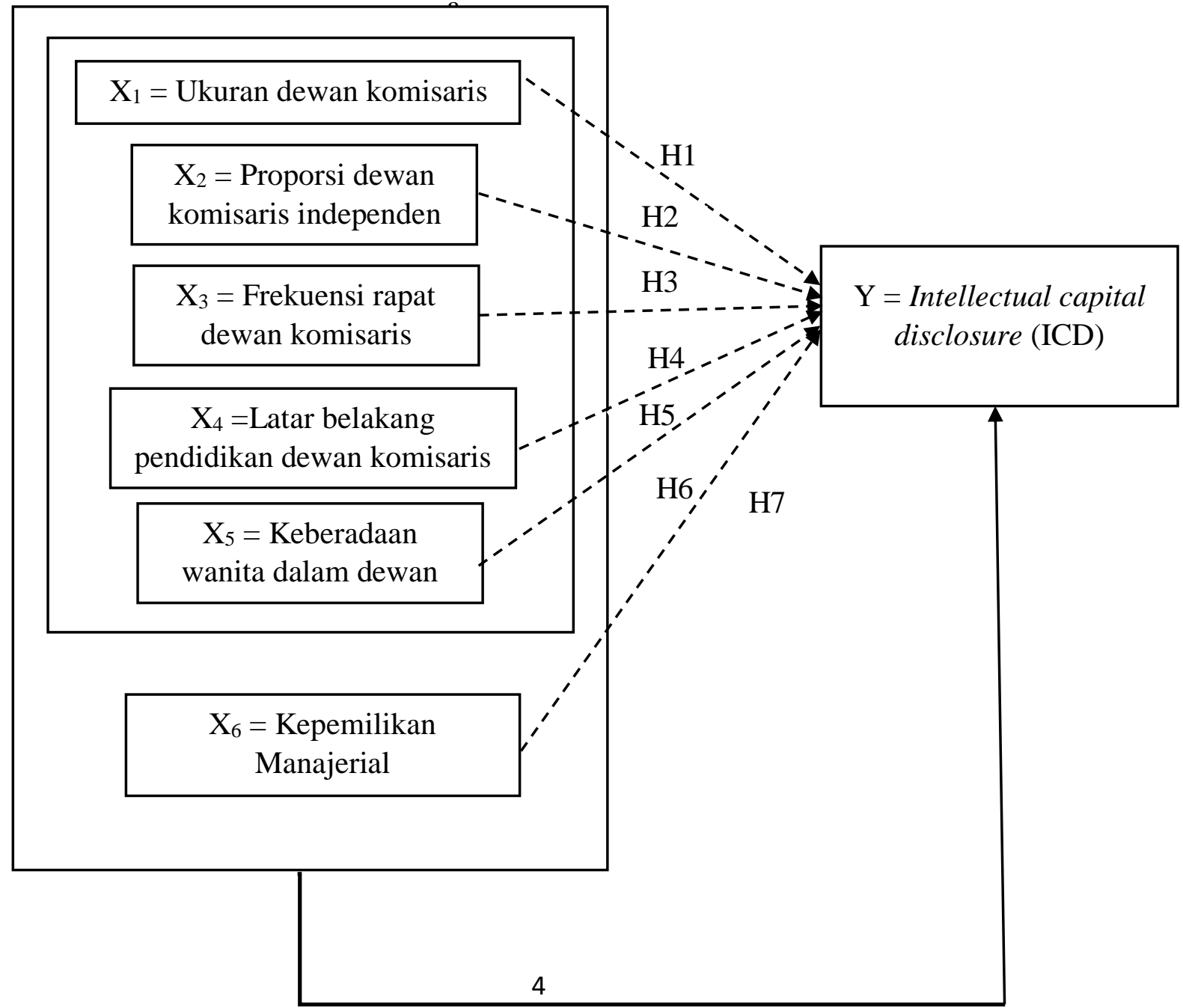


Dilihat dari kerangka ikir diatas dapat diartikan bahwa variabel ukuran dewan komisaris, proporsi dewan komisaris, frekuensi rapat dewan komisaris, latar belakang pendidikan dewan komisaris, dan keberadaan wanita dalam dewan komisaris memiliki pengaruh baik secara simultan maupun parsial terhadap intellectual capital disclosure.

\section{METODE PENELITIAN}

Ruang lingkup dalam penelitian ini hanya mencakup masalah pengaruh dewan komisaris yang diproyeksikan ukuran dewan komisaris, proporsi dewan komisaris, frekuensi rapat dewan komisaris, latar belakang pendidikan dewan komisaris, keberadaan wanita dalam dewan komisaris dan kepemilikan manajerial terhadap Intellectual Capital Disclosure pada perbankan yang terdaftar di BEI. Lokasi enelitian yang dipilih adalah Galeri Investasi Syariah Bursa Efek Indonesia Universitas Islam Kadiri Jl. Sersan Surhamadji 38 Manisrenggo Nggronggo Kediri. Populasi dalampenelitian ini adalah semua perbankan yang terdaftar di BEI dan untuk menentukan jumlah samel peneliti menggunkan metode purposive samplingsehingga didapat 21 sampel perbankan BUMN dan BUMS.

\section{HASIL PENELITIAN DAN PEMBAHASAN}

Alat analisis yang digunakan dalam penelitian ini meliputi uji prasyarat yaitu terdiri dari uji normalitas, uji multikolinieritas, uji autokorelasi, uji heterokedastisitas.Uji selanjutanya yang digunakan adalah uji statistic deskriptif dan regersi linier berganda. Untuk uji hipotesis menggunakan uji $\mathrm{f}$ (simultan )dan uji $\mathrm{t}$ (parsial). Dari pengujian yang telah dilakukan didapat hasil sebagai berikut :

\section{Statistik Deskriptif}

Hasil penelitian terkait dengan variabel dependen ditunjukan sebagai berikut :

Tabel 1

\begin{tabular}{|c|c|c|c|}
\hline $\begin{array}{c}\text { Variabel } \\
\text { Depednen }\end{array}$ & Min. & Max. & Mean \\
\hline ICD & 44,00 & 68,00 & 59,93 \\
\hline
\end{tabular}

Berdasarkan hasil uji statistik deskriptif yang telah dilakukan menampilkan hasil pengujian terhadap intellectual caital disclosure perbankan di Indonesia. Hasil dari pengujian tersebut menunjukan nilai mean atau rata-rata sebesar 59,936 hal ini berarti tingkat iintelectual capital disclosure perbank di Indonesia sebesar 59,93\% pada periode 2015-2017 melebih tinggi 5\% dari penelitian yang dilakukan pada tahun 2015 .

\section{Uji Regresi Linier Berganda}

Persamaan regresi linier berganda dapat dilihat dari kolom Unstandarlizes Coefficients pada bagaian B. berikut adalah tabel Unstandarlizes Coefficients pada bagaian B : 
Tabel 2

Hasil SPSS Uji Regresi Linier Berganda

\begin{tabular}{|l|c|}
\hline \multicolumn{1}{|c|}{ Variabel Independen } & Nilai B \\
\hline Ukuran dewan komisaris & 1,811 \\
\hline Boad of Commisioner Independent & 0,128 \\
\hline Frekuensi Rapat Dewan Komisaris & 1,585 \\
\hline Board of Commisioner Education & 0,068 \\
\hline Board of Commisioner Female & 0,002 \\
\hline Kepemilikan Manajerial & 3,869 \\
\hline
\end{tabular}

Dengan demikian persamaan garis regresinya adalah :

$\mathrm{Y}=1,811 \mathrm{X}_{1}+0,128 \mathrm{X}_{2}+1,585 \mathrm{X}_{3}+0,068 \mathrm{X}_{4}+0,002 \mathrm{X}_{5}+3,869 \mathrm{X}_{6}$

Berdasarkan persamaan diatas dapat diartikan bahwa $\mathrm{X}_{1}$ yaitu ukuran dewan komisaris bernilai positif atau mengalami kenaikan maka ICD sebagai variabel dependen akan mengalami kenaikan juga. Begitupun juga $X_{2}$ yaitu proporsi dewan komisaris independen yang memiliki nilai positif maka ICD akan mengalami kenaikan. Untuk $\mathrm{X}_{3}$ yaitu frekuensi rapat dewan komisaris mengalami kenaikan karena bernilai positif sehingga ICD juga akan mengalami kenaikan. $\mathrm{X}_{4}$ yaitu latar belekang pendidikan dewan komisaris bernilai positif sehingga jika latar belakang pedidikan dewan komisaris mengingkat ICD dalam perusahaan juga akan mengalami kenaikan. $\mathrm{X}_{5}$ dalam penelitian ini adalah keberadaan dewan komisaris wanita memiliki nilai positif sehingga jika keberadaan wanita dalam dewan komisaris ditingkatkan makan ICD juga akan meningkat. Terakhir $\mathrm{X}_{6}$ yaitu kepemilikan manajerial memiliki nilai yang positif maka ICD akan meningkat karena kepemilikan manajerial juga meningkat.

\section{Uji f (Simultan)}

Uji f dilakukan untuk menguji apakah semua variabel independen atau bebas dimasukkan dalam model mempunyai pengaruh secara simultan terhadap variabel dependen/terikat. Berikut adalah hasil uji $f$ (Simultan) yag telah dilakukan :

Tabel 3

Hasil SPSS Uji f (Simultan)

\begin{tabular}{|c|c|c|c|c|}
\hline $\begin{array}{c}\text { Variabel } \\
\text { Dependen }\end{array}$ & $\begin{array}{c}\mathrm{F} \\
\text { Hitung }\end{array}$ & $\begin{array}{c}\text { Nilai } \\
\text { Sig. }\end{array}$ & Syarat & Ket. \\
\hline ICD & 3,484 & 0,005 & $<0,05$ & $\begin{array}{c}\mathrm{H}_{7} \\
\text { diterima }\end{array}$ \\
\hline
\end{tabular}

Berdasrkan hasil SPSS diperoleh hasil $F_{\text {hitung }}$ sebesar 3,484 dengan nilai sig sebesar 0,005. Oleh karena nilai sig < 0,05 maka Ho ditolak yang artinya ukuran dewan komisaris, proporsi dewan komisaris independen, frekuensi rapat dewan komisaris, latar belakang pendidikan dewan komisaris, keberadaan dewan komisaris wanita dan kepemilikan manajerial secara simultan memiliki pengaruh terhadap intellectual capital disclosure (ICD). 
Jurnal Cendekia Akuntansi Vol. 1 No. 1

\section{Uji t (Parsial)}

Uji t adalah jenis pengujian statistik yang digunkan untuk mengetahui seberapa jauh pengaruh variabel independen dapat menerangkan variabel dependen secara individual. Berikut adalah hasil uji $\mathrm{t}$ (Parsial) yag telah dilakukan

Tabel 4

Hasil SPSS Uji Statistik t (Parsial)

\begin{tabular}{|l|l|c|c|c|}
\hline $\begin{array}{c}\text { Variabel } \\
\text { Dependen }\end{array}$ & \multicolumn{1}{|c|}{ Variabel Independen } & $\begin{array}{c}\mathbf{t} \\
\text { Hitung }\end{array}$ & $\begin{array}{c}\text { Nilai } \\
\text { Sig. }\end{array}$ & Syarat \\
\hline ICD & Ukuran Dawan Komisaris & 3.929 & .000 & $<0,05$ \\
\cline { 2 - 5 } & $\begin{array}{l}\text { Proporsi Dewan Komisaris } \\
\text { Independen }\end{array}$ & 2.200 & .032 & $<0,05$ \\
\cline { 2 - 5 } & Frekuensi Rapat & 2.407 & .019 & $<0,05$ \\
\cline { 2 - 5 } & Latar Belakang Pendidiakn & 2.503 & .015 & $<0,05$ \\
\cline { 2 - 5 } & Keberadaan Wanita & .040 & .968 & $>0,05$ \\
\cline { 2 - 5 } & MGR & .494 & .623 & $>0,05$ \\
\hline
\end{tabular}

Berdasarkan uji statistik yang telah dilakukan, diketahui bahwa variabel ukuran dewan komisaris, proporsi dewan komisaris independen, frekuensi rapat dewan komisaris dan latar belakang pendidikan dewan komisaris berpengaruh terhadap intellectual capital disclosure.Sedangkan keberadaan wanita dan kepemilikan manajerila tidak berpengaruh terhadap intellectual capital disclosure.

\section{KESIMPULAN DAN SARAN}

1. Kesimpulan

Dari penelitian yang telah dilakukan yaitu untuk mengetahui pengaruh dewan komisaris dan kepemilikan manajerila terhadap intellectual capital disclosure.Terdapat 4 variabel yang berpengarug terhadap intellectual capital disclosure yaitu ukuran dewan komisaris, proporsi dewan komisaris independen, frekuensi rapat dan latar belakang pendidikan. Hal ini dapat diartikan bahwa perbankan mengungkapkan pengetahuan yang dimiliki oleh dewan komisaris dimana pengetahuan ini dapat memberikan prospek masa depan perbankan itu sendiri. Kanaikan ini juga mengakibatkan pengungkapan intellectual capital disclosure juga mengalami kenaikan sebesar 5\% dibandingkan dengan tahun 2015.

\section{Saran}

Dapat menggunakan variabel lain yang memiliki hubungan dengan intellectual capital disclosure salah satunya adalah usia dewan komisaris. Selain menggunakan variabel baru yaitu umur dewan komisaris peneliti selanjutnya juga dapat mengganti latar pendidikan dewan komisaris dengan teknologi informasi. Peneliti selanjutnya juga dapat meneliti di sektor lain selain perbankan, sektor lain yang dapat diteliti adalah sektor properti dimana pada tahun ini pemerintah banyak melaukakn pembangunan yang membutuhkan tenaga dari perusahaan properti. 
Jurnal Cendekia Akuntansi Vol. 1 No. 1

\section{DAFTAR PUSTAKA}

Hartrianto, Andhikanandono \& Julianti Sjarief. 2017. Analisis Pengaruh Proporsi Komisaris Independen, Kepemilikan Manajerial, dan Kualitas Auditor Eksternal Terhadap Pengungkapan Intellectual Capital Pada Perusahaan ManufakturYang Terdaftar Di Bursa Efek Indonesia. Jurnal Akuntansi. No. 2 April, h 206-229.

Kuswiratmo, A. B. 2016, Keuntungan dan Risiko Menjadi Direktur, Komisaris, dan Pemegang Saham, Jakarta: Transmedia Pustaka.

Shella, Wedari, L, K. 2016. Intellectual Capital dan Intellectual Capital Disclosure Terhadap Market Performance Pada Perusahaan Publik Indeks LQ-45.Jurnal AKuntansi dan Auditing Indonesia, No. 20 Januari, h 28-36.

Suhardjanto, D. \& Wardhani M. 2010.Praktik Intellectual Capital Disclosure Perusahaan yang Terdaftar di Bursa Efek Indonesia.JAAI, 14 (1), h 7185.

Tarigan, Josua \& CHristiawan, Yulius Jogi. 2017. Kepemilikan Manajerial: Kebijakan Hutang, Kinerja dan Nilai Perusahaan. Jurnal Akuntansi Universitas Kristen Petra, Vol. 9, No. 1 (Mei), h 1-8.

Ulum.Ihayul, 2017.Intellectual Capital, Malang: Universitas Muhammadiyah Malang.

Wiryadi, R. L., \& Sabrina, N. 2013.Pengaruh Asimetri Informasi, Kualitas Audit, dan Struktur Kepemilikan Terhadap Manajemen Laba, Jurnal Wahana Riset Akuntansi , No. 1, 2, h 155 - 180.

Zarkasti, W. M. 2008, Good Corporate Governance, Bandung: ALFABETA CV. 